\title{
Multiple responsivity: strata of bodily $\operatorname{expression}^{1 *}$
}

\section{Bodily expression and the experience of the other in the phenomenological tradition}

In the present paper we analyse the multiple activity of bodily expression, differentiate its strata, relying on phenomenological and psychoanalytic traditions. We will distinguish the primordial layer of bodily expression brought to the fore by Maurice Merleau-Ponty and Daniel N. Stern from the unconscious symbolic expression captured by Freud and from the conscious symbolic bodily expression best known in everyday life. By the end we will place the multiple phenomena of bodily expression in a responsive phenomenological framework.

In the phenomenological tradition the analysis of bodily expression has been closely intertwined with the theme of other selves since Husserl's Fifth Cartesian Meditation. ${ }^{2}$ According to Husserl's analysis , the primordial sphere of bodily experience carries a peculiar duality: on the one hand I am identical to my body, I act through my body as a body-subject (Leib), but on the other hand I perceive my body as an alien, physical object which is available for others, too (Körper). This double sense of body-experience transcends the solipsistic danger philosophy inherited from Cartesian tradition. The experience of my own body carries foreign elements, while the other's body is not quite an object for me: our behaviours are intertwined, affected by each other before saying a word. The spontaneous fit of bodily expressions and behaviours is the primordial layer of experience that gives the most original, unquestionable message about the functioning of other subjects, making solipsism impossible.

This idea pushed against the limits of Husserlian interpretation of expression. Husserl considered expression generally passive, he thought of the linguistic expression as not adding any quality to the expressed thought, merely a tool. This position was left behind by the later development of phenomenology. In the philosophy of Martin Heidegger, linguistic expression opens original creative forces, and bodily attunement represents specific understanding of existence, so neither language nor body are

$1{ }^{*}$ https://doi.org/10.24361/Performa.2020.12.7

The first author's research was supported by the grant EFOP-3.6.1-16-2016-00001 (“Complex improvement of research capacities and services at Eszterházy Károly University”).

2 Husserl, Edmund: Cartesian Meditations. Dorion Cairns, trans., The Hague, Martinus Nijhoff, 1960. 
lifeless means of expression. Maurice Merleau-Ponty went even further, and made the creative event of expression a central principle of his philosophy ${ }^{3}$. According to him, there is no idea that would carry meaning in itself, ahead of a dynamic system of expressions. Thought cannot be separated from language, nor can language be independent of the liveliness of working speech: speech derives its final meaning not only from words, but also from emphasis, accent, gestures, and facial expression. This surplus of reason no longer reveals merely the thoughts of the speaker, but rather the "source of his thoughts, his basic mode of existence”. The surplus of expressive speech refers to the surplus of the bodily expression: the bodily expression is the prototype of all expressions and creations.

Responsive phenomenology further radicalized Husserl's coupling of bodily expression and otherness: not only took out bodily self-perception from the transcendental philosophical framework but reinterpreted body experience as an expression of our original responsivity. ${ }^{4}$ For the philosophy of the late Lévinas or Waldenfels the surplus of bodily expression manifests not only the hidden forces of one’s own subjectivity, but the manifestation of the original sensuous response given to the other. We are not able to escape totally from our spontaneous, primordial bodily responsiveness, but we are free to assume it, and to turn it into a blood and flesh responsibility. The responsibility becomes an ethical act, which involves not only the real perception of the other's claim but the ability of the creative answer to the alien.

\section{Bodily expression and psychoanalysis}

The theme of bodily expression was also at the heart of classical psychoanalysis, as it was Freud who discovered the immense instinctive energy in corporeality: for him, the body is no longer externally connected to the soul, but it is the inner energy source of the psyche. ${ }^{5}$ The instinct, which is the invasion of the body into the soul indirectly proclaims itself in symbolic forms of unconscious processes, dreams, utterances, unconscious actions and other symptoms. Conscious behaviours and thoughts are interpreted as unconscious expressions of hidden instincts; and in the psychoanalytic process, these unconscious, symbolic messages come to the surface, receive meaning, and become part of the self. In the post-Freudian history of psychoanalysis, the range of analysed bodily phenomena has expanded, and, like in phenomenology, the analysis of the primordial, presymbolic, implicit bodily expression has come to the fore, renewing the interpretation of therapeutic relationship, too.

\footnotetext{
3 Merleau-Ponty, Maurice: Phenomenology of Perception. Trans: Colin Smith. Routledge \& Kegan Paul. London, 1962. 4 Levinas, E.: Totalité et infini: Essai sur l'extériorité. La Haye, Martinus Nijhoff, 1971.; Lévinas, E.: Autrement qu'être ou au-delà de l'essence. La Haye, Martinus Nijhoff, 1974.;Waldenfels, B.: From Intentionality to Responsivity. In R. Bernet \& D.J. Martino (eds.), Phenomenology Today: The Schuwer Spep Lectures, 1998-2002. Pittsburg, Duquesne University, 2003.; Tengelyi L.: Tapasztalat és kifejezés. Budapest, Atlantisz, 2007.

5 Sigmund Freud: An outline of psychoanalysis. New York, W.W. Norton, 1949.
} 
Within the circle of psychoanalytic schools debating Freud's theory and competing with each other, there were attempts to interpret personal development, the formation of subjective self-senses in a phenomenological way, and not to confuse phenomenological analysis with biological explanations. Such is the case of self-psychology founded by Heinz Kohut in the 1960s, and is still developing as a contemporary form of psychoanalytic treatment. Self-psychological tradition aims to understand individuals from within, analysing their subjective experience via introspection and empathy, basing therapeutic interpretations on the understanding of the self as the central agency of the human psyche.

The most important version of self-psychology for our topic was Daniel N. Stern's theory, which created a bridge between psychoanalysis and research-based developmental models. Stern was the one who described the early events of self-organization specifically as bodily experiences and expressions. His focus was not so much on repressed, unconscious processes, but on the "implicit relational knowledge” carried in body sensations and procedural patterns. ${ }^{6}$ For Stern our early self-senses are formed by the continual work of the so called "vitality affects", which term he introduced in opposition to so-called 'categorical affects'? What is the difference between the two? Usually we think of affective experiences in terms of Darwinian affects: happiness, sadness, fear, anger, disgust, surprise, interest, and perhaps shame. Vitality affects are somewhat different, they emerge as the first, presymbolic, dynamic qualities of our existence, and of interpersonal relatedness. We are never without them, while categorical affects come and go. We always feel them, just as we feel we are alive, as we always feel a continual, intersensory affect of our moving and perceiving body, interconnected with its surroundings and with other living creatures. Vitality affects form the special qualities of first, presymbolic self-senses and early interpersonal relatedness. The mother bends to her baby, the baby raises its head, the mother caresses the head, the baby uses its voice, and the mother responds saying something in the same rhythm. There is an unconscious interpersonal and intersensory attunement of motions and perceptions, forming a common tissue of their lives. The baby feels the mother's movements, which fit to its own movements, and this joining forms the baby's self-perception. The care-giver continually mirrors, reflects and validates the baby's emerging self-senses; this vital fitting is very close in the first months, but later reduces in intensity. This intermodal-interpersonal fitting, and at the same time a differing interplay forms the grounding for self-development in the course of which the child assumes the sense of being an entity distinct from other objects in its environment. ${ }^{8}$ If the child does not get adequate responses from the parents, her/his implicit relational knowing with the vital "core” of the self gets damaged. The perpetual movement of vitality affects creates and recreates the core of our self, the fundamental moods of our 6 Stern, N. Daniel: The Present Moment in Psychotherapy and Everyday Life. New York, W. W. Norton \& Company, 2004.

7 Stern, N. Daniel: The Interpersonal World of the Infant, A View from Psychoanalysis and Development Psychology. New York, Basic Books, 1985. 53-61.

8 Stern, N. Daniel: The Interpersonal World of the Infant. 72-92. 
personality for the whole of our lives from beginning to end.

The exploration of vitality affects and implicit relational knowledge changed psychoanalytic thinking, freed it from some remnants of Cartesian dualism, similarly, as the analysis of lived body has played a key role in overcoming dualism and solipsism in phenomenological tradition. Daniel Stern's theory of self-development is congenial with the body-phenomenology of Merleau-Ponty, and we will rely on both theories when differentiating presymbolic and symbolic dimensions of bodily expression.

\section{Merleau-Ponty: The body as original source of expression}

In the phenomenological philosophy of Maurice Merleau-Ponty, the moving, perceiving, understanding body presents itself as an existential modality. We do not have our body; we are our body. We live the meaningful life of our body. It is an original field of creativity, a primordial source of all higher expressi$\mathrm{on}^{9}$. Corporeal expression is similar to the expressivity of the arts. As in the case of the arts, the content of corporeal expression is inseparable from the expression itself; and what is more, the expression is inseparable from the person who is being expressed. "The body is to be compared, not to a physical object,

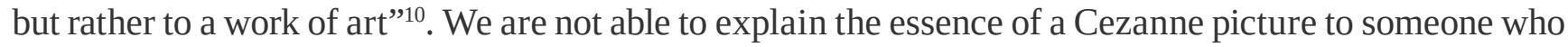
has never seen it, to express a Mozart sonata to someone who has never heard it. "In a picture or a piece of music the idea is incommunicable by means other than the display of colours and sounds"11. "A novel, poem, picture or musical work are individuals, that is, beings in which the expression is indistinguishable from the thing expressed, their meaning accessible only through direct contact..." ${ }^{12}$ Similarly, the expression of a human face or a moving body bears a certain style, an implicit meaning, which we are not able to translate to other languages. Moreover, in the case of bodily expression, not only expression and expressed content are the same, but the individual who is expressed coincides with the expression itself. While the works of arts as a poem or a sculpture express the artist symbolically and indirectly, bodily movement expresses the person not only symbolically, but also immediately and directly. There is a certain style of touching and seeing, walking and sitting, crying and laughing which makes possible the original intersensory integration of body experiences and makes possible personal identity as well. This fact gives a special strength to corporeal expression. That is why human body and movement carry an original expressive character ${ }^{13}$.

9 Merleau-Ponty, Maurice: Phenomenology of Perception. Trans: Colin Smith. London, Routledge \& Kegan Paul, 1962. 150 .

10 Merleau-Ponty, Maurice: Phenomenology of Perception. 150.

11 Merleau-Ponty, Maurice: Phenomenology of Perception. 150.

12 Merleau-Ponty, Maurice: Phenomenology of Perception. 151.

13 Merleau-Ponty, Maurice: Phenomenology of Perception. 146. 
Already Max Scheler has shown that behind the movements of anger is not anger as a "mental state," behind the gestures of or joy or boredom is not another joy, or another boredom. We perceive shame in blush itself, joy in laughter. ${ }^{14} \mathrm{I}$ do not infer the joy from the expression on my own face, but I feel the joy. I do not perceive the other as an external object as a sign, or image that refers to the psyche, but I see her as a subject of her living body. The body can symbolize existence because it realizes it and it is its own actuality. Although the bodily expression is similar to the artistic expression, it also has a peculiar surplus over the work of art: not only the expression and the expressed content coincide, but the work itself is one with the creator.

Of course bodily expression is not always immediate and integrated. We perceive the world through our body, but at the same time we perceive our own body as an object in the world. As we had showed before, the "double-sensation” of the body has been a central topic in phenomenology. We feel our body in two different ways: on the one hand it is a primordial subjective style of our movements and perceptions, on the other hand we can perceive it as an object for others and for ourselves; we can use our body as a tool, as an instrument of expression. Bodily expression has presymbolic and symbolic strata. We are able to feel the implicit senses of our body, but we are also able to bracket our body-senses for a while; we are able to suppress or conceal them. Shaking hands, turning our back to someone, or clapping at political gatherings - these intentional gestures are explicit, mostly symbolic, or conventional. We are able to express or hide ourselves with them, and we can use them as portable instruments of expression. But even in these cases, an implicit, presymbolic level is at work throughout the process of bodily self-expression: we are the ones who use ourselves like this; we are the ones who make gestures like this. In the background of these symbolic acts, we feel our own movements, we feel our own body somehow, as a non-symbolized sense-horizon of all our movements and perceptions. Our symbolic acts always have a nonsymbolic, existential background of our body as an existential modality, which we can never utterly leave behind. The original style of our movement and perception always remains with us: it is the vital source of any acts of symbolization.

\section{Strata of bodily expression}

\section{Conscious symbolic bodily expression}

The most obvious kind of bodily expression is the conscious symbolic bodily expression. There are bo-

${ }^{14}$ Max Scheler: The Nature of Sympathy. New Haven, Yale University Press, 1954. 
dily gestures in which the expresser consciously uses his body as a sign, as an instrument of expression, and the connection between the expression and the expressed meaning is a culturally encoded symbolic message. For example, we shake hands with someone, nod our heads, or clap in the theatre. The cultural regulation of bodily behaviour gives conventional meaning to human movements. However, this meaning is more or less related to the body from outside: the same gesture may mean differently in different cultures.

A special phenomenon of conscious symbolic bodily expression is bodily simulation. In this case, the body does not express itself sincerely, the simulator is hiding behind its own bodily expression with which he himself does not coincide completely. He uses his body as a sign, an instrument that does not manifest but hides the original expression. Even the usual bodily signs of anger or joy can be simulated to some extent. In such cases, bodily expressions function as consciously usable, manipulable signs: expression, expresser, and expressed content are separated from each other in these cases. The subject hides behind its expression, thus, it is not existential bodily expression that occurs, but communication with bodily signs.

\section{Unconscious symbolic bodily expression}

However, there are also symbolic manifestations of bodily expression that also refer to something beyond themselves, but they are unconscious and not manipulated by the expresser. The study of such unconscious bodily expressions set in motion classical psychoanalysis. Freud began to examine hysterical symptoms that seemed medically unjustifiable and chaotic as symbolic expressions of hidden, otherwise inexpressible contents. Let's look at an example: Merleau-Ponty writes about a case where a young girl can't swallow and talk, even though the medical cause of the swallowing and speech disorder can't be established..$^{15}$ The symptoms are made clear only by the girl's story: her parents forbade her love, but she doesn't dare confront them, yet she can't give up on her lover either. She's in a situation, which she can't stand, she can’t "swallow”. She would rather withdraw from the world of linguistic communication than have to go through the unbearable contradiction. In hysterical cases, bodily symptom is an unconscious symbolic expression of repressed and unacceptable mental conflicts. For example, hysterical blindness can occur when the patient does not want to see something, hysterical paralysis, gait disorder if she is unable to move on. These symptoms are not fixed signs, their meaning cannot be recorded in a dictionary, so hysterical disease always includes a kind of creativity - similar to expression in a dream. The hysterical symptom has no organic cause, but is involuntary, the patient cannot intentionally cause it, so it is not simulated at all. The symptom expresses ambiguous unconscious feelings from which the

${ }^{15}$ Merleau-Ponty, Maurice: Phenomenology of Perception. 185. 
patient escapes: simultaneously hides and shows the expressor who is torn, loosing unity with herself. As she hides from us, she shows something she doesn't want to show.

Of course, the unconscious symbolic bodily phenomena are not confined to the world of psychopathologies. In a milder form, healthy bodily experience also creates similar psychosomatic symbolism. If we really don't want to go to someone, we stumble more easily or get lost our way. We tend to hunch from not only physical but also mental burdens. There are many aspects of our movement, our physical behaviour, that we are not aware of, but that others are about to see as a symbolic message. Consciously unacceptable, repressed emotional impulses show themselves in the symbolic language of bodily symptoms. The expression of the hysterical girl is thus indirect: she cannot experience her anger against her parents, she does not blush into it, she does not shout. Instead of spontaneity of direct bodily expression, she can only communicate with an indirect symbolic expression, such as an inability to swallow. The indirect, symbolic meaning of her communication must be deciphered by others. Her "original”, forbidden primordial bodily expression gives place to other, substituting primordial expression of inability, which refers to a hidden feeling. We see, what a thin boundary separates the presymbolic domain from symbolic unconscious bodily expression.

\section{Primordial presymbolic bodily expression}

Here the body is not an expression of something else, but a primordial immediacy of itself. There is nothing to decipher: anger, and the one who feels it are present directly in the blush itself. I myself am my angry blush. The blush does not symbolically express some other hidden feeling, but manifests me directly. It is true that we can manipulate such bodily expressions to some degree, or we can lose them more or less, but we are able to do so because bodily expression has an original primordial layer that precedes all objectification. The various forms of symbolic expression rely on precisely these primordial, “core” bodily self-senses - as Daniel N Stern’s psychoanalytic theory explained. ${ }^{16}$ Expression of “categorical” affects are always conveyed by the stream of vitality affects, symbolic expressions are always impregnated by presymbolic, vital expressions. When I simulate, I imitate a primary expression. It is from this level that Merleau-Ponty says that the "nexus of living meanings" of the lived body is "the ability of natural expression" that precedes all symbolic meanings as its source. ${ }^{17}$ If we ask the question of what the primordial bodily expression expresses, the answer will be: not “what”, but "how”! Not “what”, but “who”! It does not express just a thought or repressed content, but it expresses a special surplus, the very source of our thoughts and repressions, it expresses the existential quality as we sense 
ourselves, as we move ourselves and respond to others

In the philosophy of Merleau-Ponty primary bodily expression is an existentiale, but not as a solitary creation: it operates in the context of a pre-existing intercorporeal field. Intercorporeity, this "unjustifiable certitude of a sensible world”, is an anonymous sensibility shared out among distinct bodies: “just as my two hands communicate across the lateral synergy of my body, I can touch the sensibility of another". ${ }^{18}$ Intercorporeal sensibility, though the most elementary intertwining with the lives of others, also carries a peculiar duality. On the one hand, the others' smiles, yawns, tensions stick to us, we cannot not tune in to the primordial expressions of others. On the other hand, we spontaneously distance ourselves form the others' states; our elementary bodily self-perception takes shape in relation to the different states of the others. The differentiation of one's own and alien experiences begins to articulate at the level of primordial bodily expressions: the more complex messages of symbolic bodily expressions rely on this original differentiation.

\section{Primordial responsivity}

Following this direction, responsive turn of phenomenology further radicalized the understanding of bodily expression. For the late Lévinas or Waldenfels the surplus of bodily expression manifests not only the existential core of one's own subjectivity, but the manifestation of the original sensible response given to the other. The quality of our actual movements, perceptions, affections carry traces of distant times, they emerge as living responses to the desires of our ancestors, finitude and aging refer to the perspectives of the descendants. Primordial sensibility is something that goes beyond the capacity of subjectivity, it has a diachronic character. As Waldenfels explains: “in the end, our bodily and embodied experiences show that I have the Other within myself and myself within the Other before we encounter each other."19

The very existence of our living body generates an ongoing implicit resonance to others, making us primordially defenceless. "Sensibility is the exposedness to the other"20. This exposedness explicitly show itself at the beginning and at the end of life, and perhaps at times of serious crisis or love, when we are totally entrusted to the others' care. But vital sensibility nurtures us, provokes us during our whole lifetime, even though we make serious efforts to eliminate our primordial exposedness.

For Daniel Stern's model of self-development the main existential problem infants have to solve

18 Merleau-Ponty, Maurice: The Visible and the Invisible. Alphonso Lingis (trans.), Evanston, Northwestern University Press, 1968. 142.

19 Waldenfels, B.: Phenomenology of the alien: Basic concepts. Evanston: Northwestern UP, 2011, 56.

20 Lévinas, I: Otherwise than Being or Beyond Essence. Th Hagus, Martinus Nijhoff Publishers, 1981, trans. Alphonso Lingis, 75. 
during the early childhood is not that how to get to be attuned to others, but how to stop original, ongoing, overwhelming attunement. ${ }^{21}$ As we saw above symbolic levels of bodily expression create distance from primordial bodily responsivity. In the case of unconscious symbolic expression the subject hides her primordial state behind another one, without knowing it, sometimes losing her integrity, and the immediate contact with other people. In the case of conscious bodily expression we directly use our body as an instrument or tool to give signs to others. We overshadow our primordial bodily responsiveness for the sake of conscious actions, for "higher" goals, necessary works, social cooperation or rivalry.

Full blown conscious activity while creating a common universe of objective meanings, signs and concepts, distances itself from the body's overwhelming sensibility. Distancing from primordial responsivity makes possible the mind's “independent” intentional activity, its objectifying, controlling work. But intentional work of consciousness — striving for a whole object structure — always extends beyond its possibilities and "thinks more" than what is available to experience. ${ }^{22}$ Its identifying activity creates symbolic meanings, “objective”, third-person orders, morals - a generality that obscures the primordial sources of our experiences. Of course we are not able to live without this third person generality, without objective knowledge, solid norms, social systems and laws. But we must not forget, that conscious subject, which creates its symbolic world has responsive origin: its own identity is articulated when addressed by others, in response to others, in the attention of others, in the dichotomy of own and foreign experiences. "Responsivity goes beyond every intentionality because responding to that which happens to us cannot be exhausted in the meaning, understanding, or truth of our response. All this is not restricted to the affective background of our cognitive and practical modes of comportment; it concerns these modes in their essence...” 23

The reception or rejection of the other takes shape first as a responsive sensibility, proceeding any kind of symbolic activity. Conscious or unconscious gestures are built on this primordial foundation. If we totally escape from our sensible exposedness, if we block the flow of vitality affects we lose our ability to receive the other, as Other. Yet if we learn to stay close to vital sources of responsivity, if we learn to mobilize its energies, we become able to provide a creative response when addressed by the other. Creative response translates our spontaneous resonances into "something else”. While responding to the alien we begin to change: we recognize ourselves in new ways. We become able to turn our spontaneous, primordial bodily responsiveness into a blood and flesh responsibility for the other. The responsibility becomes an ethical act, which involves not only the real perception of the other's claim but the ability of the creative answer to the alien.

21 Stern, N. Daniel: The Interpersonal World of the Infant. 53-61.

22 Ullmann Tamás: A láthatatlan forma. Sematizmus és intencionalitás. Budapest, l’Harmattan, 2010, 257.

23 Waldenfels, B.: Phenomenology of the alien. 28. 


\section{INDEX}

R. BERNET \& D.J. MARTINO (eds.): Phenomenology Today: The Schuwer Spep Lectures, 1998-2002. Pittsburg, Duquesne University, 2003.

Sigmund FREUD: An outline of psychoanalysis. New York, W.W. Norton, 1949.

Edmund HUSSERL: Cartesian Meditations. Dorion Cairns, trans., The Hague, Martinus Nijhoff, 1960. https://doi.org/10.1007/978-94-017-4952-7

Emmanuel LEVINAS: Totalité et infini: Essai sur l'extériorité. La Haye, Martinus Nijhoff, 1971.

Emmanuel LEVINAS: Autrement qu'être ou au-delà de l'essence. La Haye, Martinus Nijhoff, 1974. https://doi.org/10.1007/978-94-015-1111-7

Emmanuel LEVINAS: Otherwise than Being or Beyond Essence. Th Hagus, Martinus Nijhoff Publishers, 1981, trans. Alphonso Lingis.

Maurice MERLEAU-PONTY: Phenomenology of Perception. Trans: Colin Smith. Routledge \& Kegan Paul. London, 1962.

Maurice MERLEAU-PONTY: The Visible and the Invisible. Alphonso Lingis (trans.), Evanston, Northwestern University Press, 1968.

Max SCHELER: The Nature of Sympathy. New Haven, Yale University Press, 1954.

N. Daniel STERN: The Present Moment in Psychotherapy and Everyday Life. New York, W. W. Norton \& Company, 2004.

N. Daniel STERN: The Interpersonal World of the Infant, A View from Psychoanalysis and Development Psychology. New York, Basic Books, 1985.

László TENGELYI: Tapasztalat és kifejezés. Budapest, Atlantisz, 2007.

Tamás ULLMANN: A láthatatlan forma. Sematizmus és intencionalitás. Budapest, l’Harmattan, 2010. Bernhard WALDENFELS: From Intentionality to Responsivity. In R. BERNET \& D.J. MARTINO (eds.): Phenomenology Today: The Schuwer Spep Lectures, 1998-2002. Pittsburg, Duquesne University, 2003. Bernhard WALDENFELS: Phenomenology of the alien: Basic concepts. Evanston: Northwestern UP, 2011. https://doi.org/10.2307/j.ctv47wfh3 













